\title{
スポーツに起因するロ腔顎顔面外傷131例の臨床特徵
}

\author{
中西千草・額田純一郎・井手 進 策 \\ 土居敏 英・松山博道 $\cdot$ 松村達志 \\ 山田朋弘・藤本耕二**作田正義
}

\section{Clinical characteristics of 131 patients with sports-related oral and maxillofacial injuries}

\author{
Chigusa Nakanishi $\cdot$ Jun-ichiro Nukata $\cdot$ Shinsaku Ide \\ Toshihide Dor $\cdot$ Hiromichi Matsuyama $\cdot$ Tatsushi Matsumura \\ Tomohiro Yamada $\cdot$ Koji Fujimoto* $*$ Masayoshi Sakuda
}

\begin{abstract}
We assessed the characteristics of 131 patients, with sports-related oral and maxillofacial injuries treated at the Department of Oral and Maxillofacial Surgery II , Osaka University Dental Hospital during the 10-year period from 1988 to 1997.

The incidence of sport-related injuries increased significantly from 10\% in 1988 to 1992 to $15 \%$ in 1993 to 1997.

The ratio of males to females was 11:1, and the majority of patients were between the ages of 10 and 29 years.

The highest proportion of injuries $(32.1 \%)$ occurred in the summer. Injuries were caused by 24 different sports and the most common cause was baseball (25.2\%), followed by rugby $(19.1 \%)$, soccer $(13.0 \%)$, and skiing $(11.5 \%)$. Most rugby and soccer accidents were caused by collisions, between players and involved fractures. Most baseball accidents were caused by collisions with sporting goods and involved periodontal tissue injuries.

The above results suggest the need for stronger preventive and protective measures against sports-related accidents.
\end{abstract}

Key words: clinicostatistical study (臨床統計的検討), oral and maxillofacial injuries (口腔顎顔 面外傷), sports injuries（スポーツ外傷）,

\section{緒言}

スポーツに起因する顎顔面骨折に関する本邦の臨床 報告 1-2) は散見されるが, 軟組織および歯周組織の 外傷も含めたスポーツ外傷全般についての報告は涉猟 した限りでは見当たらない. そこで今回，スポーツ外 傷全般の臨床病態の特徵を検討し, 若干の知見を得た
ので報告する．

\section{対象症例および研究方法}

1988年 1 月から1997年12月までに大阪大学歯学部附 属病院第 2 口腔外科にて治療した口腔顎顔面外傷（以 下，外傷）1010症例中，スポーツ外傷131例（13.2\%）を
大阪大学歯学部口腔外科学第 2 講座

（主任：作田正義教授）

*市立伊丹病院歯科口腔外科

(主任 : 藤本耕二部長)

Second Department Oral and Maxillofacial Surgery, Faculty of Dentistry, Osaka University
(Chief: Prof. Masayoshi Sakuda)

*Department of Oral and Maxillofacial Surgery, Itami Municipal Hospital (Chief: Dr. Koji Fujimoto)

受付日：平成10年11月 2 [ 
表 1 スポーツ種目別の受傷原因

\begin{tabular}{|c|c|c|c|c|c|c|}
\hline & $\begin{array}{l}\text { 対人 } \\
\text { 衝突 }\end{array}$ & $\mid \begin{array}{l}\text { スポーツ用則 } \\
に よ る \text { 撲 }\end{array}$ & 転 倒 & $\begin{array}{l}\text { 対物 } \\
\text { 衝突 }\end{array}$ & 㩯落 & 症例計 \\
\hline 野球 & 11 & 22 & 0 & 0 & 0 & 33 \\
\hline ラグピー & 24 & 0 & 1 & 0 & 0 & 25 \\
\hline サッカー- & 16 & 1 & 0 & 0 & 0 & 17 \\
\hline スキー & 5 & 6 & 2 & 1 & 1 & 15 \\
\hline ソフトボール & 5 & 2 & 0 & 0 & 0 & 7 \\
\hline 空手 & 5 & 0 & 0 & 0 & 0 & 5 \\
\hline ドッジボール & 3 & 0 & 0 & 0 & 0 & 3 \\
\hline $\bar{\tau}$ テス & 0 & 3 & 0 & 0 & 0 & 3 \\
\hline バスケットボール & 1 & 0 & 2 & 0 & 0 & 3 \\
\hline ホッケー & 0 & 2 & 0 & 0 & 0 & 2 \\
\hline ゴルフ & 0 & 2 & 0 & 0 & 0 & 2 \\
\hline 拳法 & 2 & 0 & 0 & 0 & 0 & 2 \\
\hline バーベル & 0 & 1 & 1 & 0 & 0 & 2 \\
\hline スケート & 0 & 0 & 2 & 0 & 0 & 2 \\
\hline バレーボール & 0 & 1 & 0 & 0 & 0 & 1 \\
\hline ジョギンク & 0 & 0 & 0 & 1 & 0 & 1 \\
\hline 相撲 & 0 & 0 & 1 & 0 & 0 & 1 \\
\hline ハンドボール & 1 & 0 & 0 & 0 & 0 & 1 \\
\hline 競技用自転車 & 0 & 0 & 1 & 0 & 0 & 1 \\
\hline 鉄棒 & 0 & 0 & 0 & 0 & 1 & 1 \\
\hline 水泳 & 0 & 0 & 1 & 0 & 0 & 1 \\
\hline 陸上 & 1 & 0 & 0 & 0 & 0 & 1 \\
\hline 器械体操 & 0 & 0 & 1 & 0 & 0 & 1 \\
\hline フットボール & 1 & 0 & 0 & 0 & 0 & 1 \\
\hline 症例計（\%） & $75(57.3)$ & $40(30.5)$ & $12(9.2)$ & $2(1.5)$ & $2(1.5)$ & $131(100)$ \\
\hline
\end{tabular}

対象症例とした. 検討には診療記録および単純 X 線写 真を用い調查した.なお，スポーツ外傷の頻度および 性・年齢分布は調查期間を 1988 1992年の前期 5 年間 (以下, 前期) と1993 1997年の後期 5 年間（以下，後 期）に分け, 各時期別に検討を行った. 統計学的処置

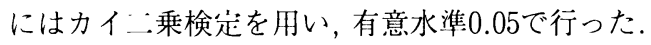

\section{結}

\section{果}

\section{1. スポーツ外傷の頻度}

外傷全体に占めるスポーツ外傷の頻度は，13.2\%で あり，また時期別にみると前期 $10.7 \%$ (484例中 52 例 ）， 後期 $15.0 \%$ (526例中79例) であり，前期に比べ後期に 各時期の外傷全体に占めるスポーツ外傷の割合が有意 に増加していた。

\section{2 .性・年齢分布}

性別では男性が120例（91.6\%)，女性が11例（8.4\%） であり，女性に比べ男性が圧倒的に多かった。また年 齢分布では20代が68例 $(51.9 \%)$ でピークを示し，次い で10代 (39.7\%) の順であった. 10代, 20代を合わせる
と全体の $91.6 \%$ 占めていた。なお，30代以後はすべ て男性の受傷であった。前期と後期のそれぞれの男女 比は両時期の間で有意な差はみられなかった。

\section{3 .受傷季節}

季節を春夏秋冬の四季でみると夏期が42例 (32.1\%) で最も多く，冬期が23例（17.6\%）で最も少なかった。 なお, スポーツ種目でみると、スキーは冬期に受傷が 多く，ラグビーおよび野球は冬期に少なかった。

4.受傷原因

受傷の原因となったスポーツ種目は, 野球が33例 (25.2\%) で最も多く, ラグビー25例 (19.1\%), サッカー 17例 (13.0\%)，スキー15例（11.5\%）の順であった.

受傷時の直接原因は競技相手との対人衝突が75例 (57.3\%) で最も多く, 次いで飛来したラケットやボー ルなどのスポーツ用具による打撲が40例（30.5\%）で あり, 転倒12例 $(9.2 \%)$ の順であった.

受傷の直接原因とスポーツ種目の関係は, 対人衝突 がラグビー24例 $(32.0 \%)$ と最も多く, 次いでサッカー 16例 $(21.3 \%)$ であり，両者を合わせると全体の $53.3 \%$ を占めていた．また，スポーツ用具による打撲では野 球が 22 例 $(55.0 \%)$ で最も多く，次いでスキー6 例 (15.0\%)，テニス 3例（7.5\%）の順であった。なお，野 球では飛来したボールによる打撲に起因する受傷が多 かった（表 1 ).

\section{5 . 外傷の種類}

スポーツ外傷131例全体の72例 $(55.0 \%)$ が顎顔面骨 折であり最も多かった．残る59例 (45.0\%) は歯槽骨 折や歯の外傷といった歯周組織外傷 52 例 (39.7\%) お よび軟組織外傷 7 例 $(5.3 \%)$ であり，歯周組織外傷が 骨体部骨折に次いで多かった。

受傷原因となったスポーツ種目別に外傷の種類をみ ると野球では歯の外傷単独が33例中11例 $(33.3 \%)$ で 最も多く,またラグビー, スキーおよびソフトボール ではすべて下顎体部骨折が最も多く，それぞれ25例中 14 例 $(56.0 \%), 17$ 例中 5 例 $(33.3 \%)$ および 7 例中 4 例 (57.1\%) であった。なお, サッカーでは顔面中 $1 / 3$ 骨 折が17例中 6 例 $(35.3 \%)$ で最も多く, 次いで下顎体部 骨折であった（表 2 ). ラグビーの下顎体部骨折を部位 別にみると，14例中11例（78.6\%）が角部であり，この 角部骨折11例の衝突時の加害対象は, スポーツ相手の 膝 3 例, 相手の頭部 2 例の順であった. また, サッカー の顔面中 $1 / 3$ 骨折 6 例中 5 例 $(83.3 \%)$ が煩骨骨折で あり,この 5 例中 3 例 $(60 \%)$ がスポーツ相手の頭部 との衝突であった。

なお，顎顔面骨折72例の種類を骨折線でみると 1 線 と 2 線がそれぞれ 34 例 $(47.2 \%) 32$ 例 $(44.4 \%)$ であり， 3 線骨折は 6 例 $(8.3 \%)$ にみられた。

\section{考察}

スポーツ外傷の頻度は本集計において外傷全体の 13.2 
表 2 スポーツ種目別の外傷の種類

\begin{tabular}{|c|c|c|c|c|c|c|c|c|}
\hline & $\begin{array}{l}\text { 軟組織 } \\
\text { 外 傷 }\end{array}$ & 歯の外傷 & 歯槽骨折 & $\begin{array}{l}\text { 関節突 } \\
\text { 起骨折 }\end{array}$ & $\begin{array}{l}\text { 下 頻 } \\
\text { 体骨折 }\end{array}$ & \begin{tabular}{|l} 
顔 面 中 \\
$1 / 3$ 骨折
\end{tabular} & \begin{tabular}{|l|} 
合併 \\
骨折*
\end{tabular} & 症例計 \\
\hline 野球 & 0 & 11 & 7 & 0 & 9 & 5 & 1 & 33 \\
\hline ラグビー & 0 & 2 & 4 & 0 & 14 & 4 & 1 & 25 \\
\hline サッカー & 0 & 2 & 2 & 3 & 4 & 6 & 0 & 17 \\
\hline スキー & 2 & 3 & 2 & 0 & 5 & 1 & 2 & 15 \\
\hline ソフトボール & 2 & 0 & 0 & 0 & 4 & 1 & 0 & 7 \\
\hline 空手 & 0 & 0 & 0 & 0 & 3 & 1 & 1 & 5 \\
\hline ドッジボール & 0 & 3 & 0 & 0 & 0 & 0 & 0 & 3 \\
\hline テニス & 1 & 2 & 0 & 0 & 0 & 0 & 0 & 3 \\
\hline バスケットボール & 0 & 1 & 2 & 0 & 0 & 0 & 0 & 3 \\
\hline ホッケー & 0 & 1 & 0 & 0 & 1 & 0 & 0 & 2 \\
\hline ゴルフ & 0 & 0 & 1 & 0 & 1 & 0 & 0 & 2 \\
\hline 拳法 & 1 & 0 & 0 & 0 & 0 & 0 & 1 & 2 \\
\hline バーベル & 0 & 1 & 1 & 0 & 0 & 0 & 0 & 2 \\
\hline スケート & 0 & 2 & 0 & 0 & 0 & 0 & 0 & 2 \\
\hline バレーボール & 0 & 1 & 0 & 0 & 0 & 0 & 0 & 1 \\
\hline ジョギング & 0 & 0 & 0 & 0 & 0 & 0 & 1 & 1 \\
\hline 相撲 & 0 & 0 & 0 & 0 & 1 & 0 & 0 & 1 \\
\hline ハンドボール & 0 & 1 & 0 & 0 & 0 & 0 & 0 & 1 \\
\hline 競技用自転車 & 0 & 1 & 0 & 0 & 0 & 0 & 0 & 1 \\
\hline 鉄棒 & 0 & 0 & 0 & 1 & 0 & 0 & 0 & 1 \\
\hline 水泳 & 0 & 1 & 0 & 0 & 0 & 0 & 0 & 1 \\
\hline 陸上 & 0 & 1 & 0 & 0 & 0 & 0 & 0 & 1 \\
\hline 器械体操 & 1 & 0 & 0 & 0 & 0 & 0 & 0 & 1 \\
\hline フットボール & 0 & 0 & 0 & 0 & 0 & 0 & 1 & 1 \\
\hline 症例計（\%） & $7(5.3)$ & $33(25.2)$ & 19(14.5) & $4(3.1)$ & $42(32.1)$ & 18(13.7) & $8(6.1)$ & $131(100)$ \\
\hline
\end{tabular}

*下顎体と顔面中 $1 / 30$ 合併骨折
などであった

外傷の種類では, ラグビーやサッカーな どのコンタクトスポーツに対人衝突によ る顔面骨の骨体骨折が多く,これらのスポー ッでは衝突時の外力が非常に大きいこと が背景にあったためと考えられる。とくに ラグビーでは下顎体角部骨折が多く, サッ カーでは顔面中 $1 / 3$ 骨折が多かった。これ ら骨折の発症については, ラグビーでは競 技中の夕ックルの際などに相手の体の一 部と下顎体が衝突する機会が多く, またサッ カーでは相手の頭部と规骨の衝突が多かっ た.また，本集計にてスポーツ用具による 打撲に起因する受傷が目立っていた野球 では, 歯の外傷が多く特徵的であった。し かしながら，辻口ら ${ }^{3)}$ の形成外科領域の 報告では，野球による鼻骨骨折が多かった としている。このように報告者間でみられ る好発スポーツ外傷の種類の相違は, 患者 が受診した診療科の専門領域により影響 を受けるものと思われる.

鈴木ら ${ }^{2)}$ は, スポーツ外傷による下顎 骨骨折症例において骨折線はすべて 1 線 ないし 2 線であったと報告し，また交通外 傷に見られるような複雑な骨折や重篤な 骨折は少ないとの報告 ${ }^{3)}$ がある。しかし ながら本集計結果では， 3 線骨折などの重 症症例もみられることから, スポーツ外傷 の予防および事故時の顎顔面保護を講じ る対策の必要性が強く示唆される。

\section{結語}

スポーツに起因する顎顔面外傷 131 症例の臨床特徵 について検討した結果, おのおののスポーツ特性にあっ た事故防止や顎顔面保護の対策の必要性が示唆された。

\section{引用 文 献}

1）田中信幸, 君島 裕, 他：スポーツに起因する 顎顔面骨骨折の臨床統計. 日口外志 42:314-316 1996.

2）鈴木 円, 東條方厚, 他：スポーツに起因した 䫟顔面骨骨折の臨床統計的観察. 臨床スポーツ 医学 14:593-596 1997.

3）辻口幸之助, 田嶋定夫：スポーツ外傷におけ る顔面外傷. MB Orthop 7: 17-25 1994 .

4）榊田喜三郎, 山本 真監修 : スポーツ外傷・障 害の予防と治療. 第 1 版, 南江堂, 東京, 1988, 23-61 頁. 